\title{
Initial experience with a reversal-of-flow cerebral protection device in carotid angioplasty
}

\author{
Experiência inicial com dispositivo de reversão de fluxo \\ para proteção cerebral na angioplastia carotídea
}

Sidnei José Galego 1,2,3, Dino Fecci Colli Junior², Reinaldo Donatelli³, Marcos Antonio Pereira Cardoso3, Anderson Nadiak Bueno ${ }^{3}$, Armando Carvalho de Lobato², João Antonio Corrêa', Salomão Goldman³

\begin{abstract}
Purpose: To report initial findings with the GORE Flow Reversal System ${ }^{\oplus}$, with a focus on major/minor adverse events in the 30 first postoperative days. Methods: The first 24 patients submitted to carotid angioplasty using the GORE system, from June 2010 to May 2012, were retrospectively assessed with regard to indications, anatomic details, technical difficulties, and early clinical outcomes, including major (stroke, death, acute myocardial infarction) and minor (hematoma) adverse events. Results: Systemic hypertension was present in $100 \%$ of the patients, diabetes mellitus in 58.3\%, and coronary disease in 37.5\%. Type II aortic arch was encountered in $62.5 \%$ of the patients and atherosclerotic lesion predominantly at the carotid bifurcation affecting the internal and common carotid arteries in 79.2\%. Angiographic data revealed contralateral carotid arteries with $<50 \%$ stenosis in $95.8 \%$ of cases and preservation of cerebral blood flow in 95.8\%. All procedures but one were technically successful. Mean cerebral flow reversal time was 14.9 minutes, with a statistically significant difference between the first 12 ( 17.9 minutes) and the last 12 patients treated (11.6 minutes) ( $p<0.001)$. Intolerance to flow reversal was observed in $17.4 \%$ of the cases. Technical difficulties were experienced in 1 patient (4.2\%). Clinical outcomes included 4.2\% of stroke and $12.5 \%$ of hematomas at arterial puncture sites. Conclusion: The system was technically effective. A significant reduction in cerebral flow reversal time was observed, and the rates of early major/minor adverse events were within acceptable limits, suggesting that the device is safe and effective.
\end{abstract}

Keywords: angioplasty; cerebral protection; complications.

\section{Resumo}

Objetivo: Relatar os achados iniciais da utilização do GORE Flow Reversal System (Sistema de Fluxo de Reversão), com foco em eventos adversos maiores/menores nos primeiros 30 dias do pós-operatório. Métodos: Os primeiros 24 pacientes submetidos a angioplastia carotídea com a utilização do sistema GORE, de junho de 2010 a maio de 2012, foram avaliados retrospectivamente com relação a indicações, detalhes anatômicos, dificuldades técnicas e desfechos clínicos imediatos, incluindo eventos adversos maiores (acidente vascular cerebral, morte, infarto agudo do miocárdio) e menores (hematoma). Resultados: Hipertensão sistêmica estava presente em 100\% dos pacientes, diabete melito em 58,3\% e doença coronariana em 37,5\%. Arco aórtico tipo II foi encontrado em 62,5\% dos pacientes e lesão de aterosclerose predominantemente na bifurcação carotídea que afeta as artérias carótidas internas e comuns em 79,2\%. Dados angiográficos revelaram artérias carótidas contralaterais com estenose $<50 \%$ em 95,8\% de casos e preservação de fluxo sanguíneo cerebral em $95,8 \%$. Todos os procedimentos, com exceção de um, foram tecnicamente bem sucedidos. A média do tempo de reversão do fluxo cerebral foi de 14,9 minutos, com uma diferença estatisticamente significativa entre os primeiros 12 pacientes (17,9 minutos) e os últimos 12 pacientes tratados (11,6 minutos) ( $p<0,001)$. Intolerância à reversão de fluxo foi observada em 17,4\% dos casos. Ocorreram dificuldades técnicas em 1 paciente (4,2\%). Desfechos clínicos incluíram 4,2\% de acidente vascular cerebral e 12,5\% de hematomas em locais de punção arterial. Conclusão: $\mathrm{O}$ sistema foi tecnicamente eficaz. Uma redução significativa no tempo de reversão do fluxo cerebral foi observada e as taxas de eventos adversos maiores/menores ficaram dentro de limites aceitáveis, sugerindo que o dispositivo é seguro e eficaz.

Palavras-chave: angioplastia; proteção cerebral; complicações.

\footnotetext{
'Faculdade de Medicina do ABC - FMABC, São Paulo, SP, Brazil.

${ }^{2}$ Instituto de Cirurgia Vascular e Endovascular de São Paulo - ICVE-SP, São Paulo, SP, Brazil.

${ }^{3}$ Hospital São Luíz - Unidade Brasil, Santo André, SP, Brazil.

Financial support: WL Gore and Associates (partial support for author training).

Conflict of interest: No conflicts of interest declared concerning the publication of this article

Submitted on: 21.08.12. Accepted on: 28.11.12.
}

This study was carried out at Hospital de Ensino da Faculdade de Medicina do ABC, ICVE - Instituto de Cirurgia Vascular e Endovascular de São Paulo, and Hospital São Luís - Unidade Brasil - Santo André, state of São Paulo, Brazil.

WL Gore and Associates partially funded author training but did not have any role in study design, data collection and analysis, or manuscript approval. 


\section{INTRODUCTION}

Several studies conducted in the United States have reported good results with the GORE Flow Reversal System ${ }^{\circledast}$. Whitlow et al., ${ }^{1}$ in a multicenter study involving 75 patients, did not record any case of stroke or death, and only $5 \%$ of the patients presented transient ischemic attack. More recently, the EMPiRE study, by Clair et al., ${ }^{2}$ prospectively assessed 245 patients submitted to carotid stenting using the GORE Flow Reversal System ${ }^{\circledR}$ over the first 30 postoperative days. The authors found $4.5 \%$ of major adverse events (stroke, death, or acute myocardial infarction) and $2.4 \%$ of intolerance to flow reversal. To the authors' knowledge, however, no study has so far been conducted in Brazil to assess this new system, the difficulties involved in its use, technical results, and early clinical outcomes.

Therefore, the aim of the present study was to retrospectively describe the initial experience of a group of Brazilian vascular surgeons with the use of the GORE Flow Reversal System ${ }^{\circledR}$ for cerebral protection in carotid angioplasty over a 24-month period, in terms of technical effectiveness and clinical follow-up data, with a focus on the rate of early major and minor adverse events (within 30 days after the procedure).

\section{METHODS}

\section{Sample selection and characteristics}

The first 24 patients submitted to carotid angioplasty using the GORE Flow Reversal System ${ }^{\circledR}$, from June 2010 to May 2012, were retrospectively analyzed. The following parameters were assessed: indications, anatomy encountered during surgery, technical difficulties faced during the procedure, and early clinical outcomes, including major and minor adverse events.

Mean age was 71.2 years, and 14 patients (58.3\%) were male. All patients presented comorbidities, high surgical risk, and stenosis $>70 \%$ at the carotid bifurcation or internal carotid. Measurement of stenosis was performed according to criteria set forth in the North American Symptomatic Carotid Endarterectomy Trial (NASCET) ${ }^{3}$. All carotid angioplasty procedures were performed by the same surgeon, at three different centers located in São Paulo, Brazil.

Fourteen patients were symptomatic; among the remaining asymptomatic patients (nine), one presented asymptomatic carotid restenosis. Symptomatic patients were defined as those presenting with stroke or transient ischemic attack, or signs suggestive of embolization, such as amaurose fugax 3 months before the procedure.

The following inclusion criteria were taken into consideration during patient selection: presence of atheromatous plaque (internal carotid or carotid bifurcation); embolism symptoms (transient ischemic attack or stroke more than 30 days before or stenosis $>70 \%$ at angiography or computed tomographic angiography); restenosis at the carotid bifurcation; high carotid bifurcation (above C2); presence of comorbidities (coronary disease, heart failure, decreased ejection fraction, uncontrolled diabetes). Patients with a history of recent stroke (less than 21 days before enrolment), with renal failure (serum creatinine level $>2.5 \mathrm{mg} \%$ ), coagulation disorders or blood transfusion refusal, and those with carotid stenosis $<50 \%$ or stenosis affecting the contralateral carotid artery, were excluded.

Follow-up time ranged from 0.7 to 22.3 months, at a mean \pm standard deviation of $13.3 \pm 7.4$ months for the whole sample. No patient was lost to follow-up.

All patients signed an informed consent form prior to inclusion in the study. The study protocol was approved by the Brazilian National Research Ethics Committee (CONEP, protocol no. FR-452360).

The following variables were analyzed: 1) anatomic data: aortic arch (types I, II, and III), atheromatous plaque location at the carotid bifurcation, and cerebral circulation before and after the procedure; 2) technical data: type of stent used for cerebral protection, time of flow reversal, intolerance to flow reversal (defined as absence of verbal or cognitive response during flow reversal); 3) clinical data: presence of comorbidities, such as hypertension, diabetes mellitus, coronary disease, chronic obstructive pulmonary disease, renal failure, and smoking; 4) clinical outcomes, including major adverse events, such as stroke, death and acute myocardial infarction, and minor events, such as hematomas, pseudoaneurysms, and abnormalities on carotid Doppler ultrasound.

\section{System components}

The GORE Flow Reversal System ${ }^{\circledR}$ (WL Gore and Associates, Flagstaff, AZ, USA) comprises three main components, namely a balloon sheath for distal occlusion of the common carotid artery, a hypo tube shaft, which includes a smaller balloon for occlusion of the external carotid artery, and a $180-\mu \mathrm{m}$ external filter.

\section{Surgical technique}

Surgical procedures are illustrated in Figure 1. Briefly, the femoral artery and the contralateral 


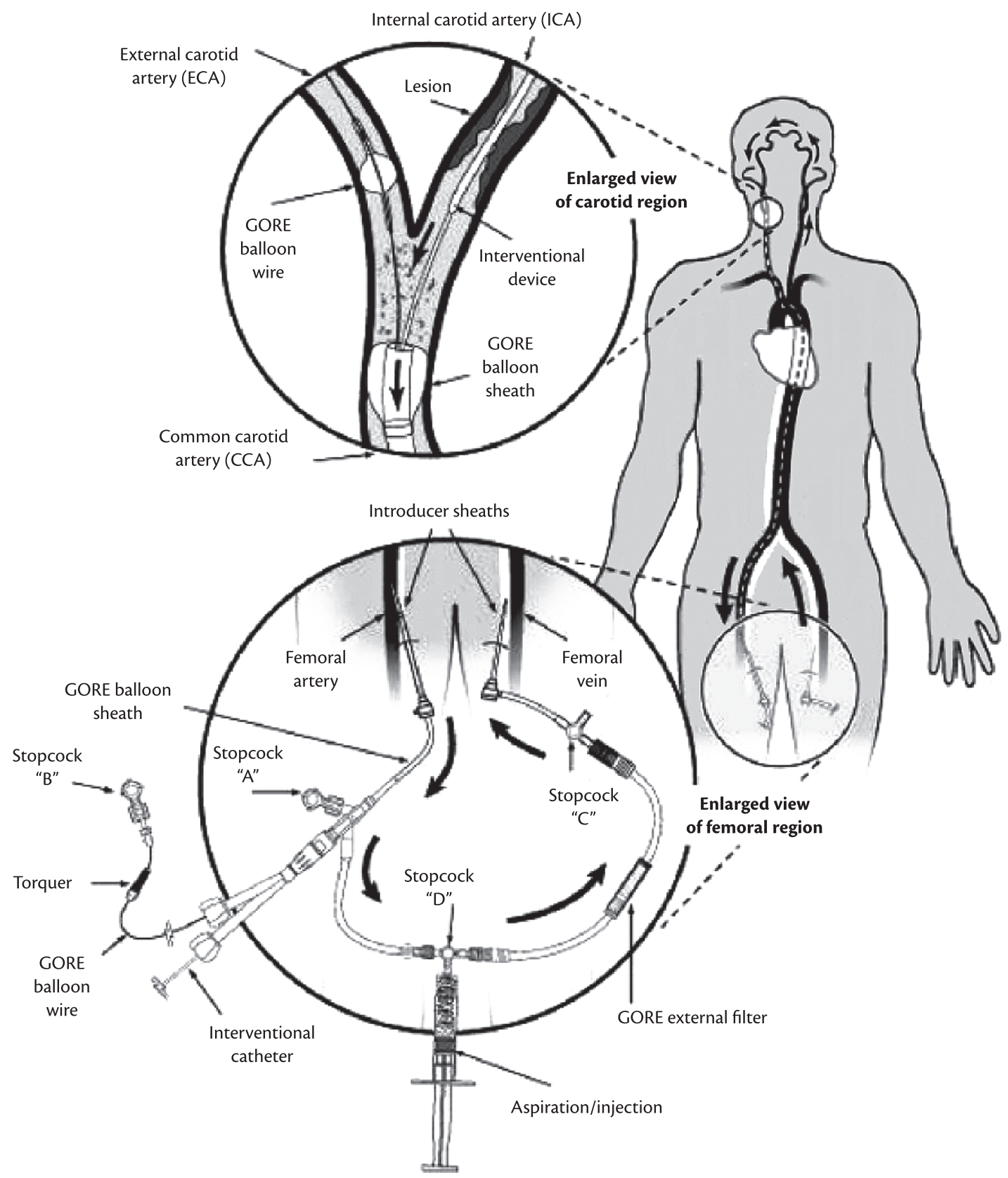

Figure 1. Schematic representation of the GORE Flow Reversal System ${ }^{\bullet}$ (image obtained from WL Gore \& Associates).

femoral vein were punctured using a $11-\mathrm{cm} 5 \mathrm{Fr}$ introducer on the arterial side and a $11-\mathrm{cm} 7 \mathrm{Fr}$ introducer on the venous side. The external carotid artery was catheterized using a hydrophilic guide wire, and a diagnostic catheter was advanced into the vessel for selective catheterization of the common carotid artery to be treated. Then, the hydrophilic guide wire was replaced with an extra stiff guide wire, to support the passage of the flow reversal system.
The introducer used on the arterial side was replaced with a $9 \mathrm{Fr}$ sheath, to allow introduction of the balloon sheath for distal occlusion of the common carotid artery. Following vacuum application, the distal balloon was advanced until reaching the common carotid artery, accompanied by a radiopaque dilator, which was withdrawn after correct positioning of the balloon sheath. Subsequently, the external filter was positioned to create an arteriovenous fistula, allowing flow reversal 
from the carotid arterial system to the contralateral femoral venous system, as a result of differences in pressure. Finally, the hypo tube shaft was inserted via the corresponding valve, and selective catheterization of the external carotid artery was performed with the hypo tube balloon deflated. The balloon positioned at the external carotid artery was inflated, followed by inflation of the common carotid artery balloon, and flow reversal was then established. Angiographic monitoring was performed throughout the procedure (Figure 2).

Following flow reversal, carotid angioplasty was performed according to the conventional technique. Briefly, a 0.014" guide wire was advanced through the lesion, and the stent model selected for each patient was positioned and deployed; balloon angioplasty was performed subsequently. In one case of carotid restenosis, only a Cutting Balloon ${ }^{\circledR}$ (Boston Scientific, Natick, MA, USA) was inflated. After treatment, the balloon positioned at the external carotid artery was deflated first, followed by the balloon in the common carotid artery.

Perioperative medication management consisted of antiplatelet therapy with clopidogrel $75 \mathrm{mg}$ twice daily starting at least 48 hours before surgery and maintained for 90 days after the procedure. Heparin at $5000 \mathrm{U}$ was administered during the procedure by intravenous bolus infusion.

All procedures were carried out under local anesthesia local and minimal sedation, using midazolam. The level of consciousness and motor
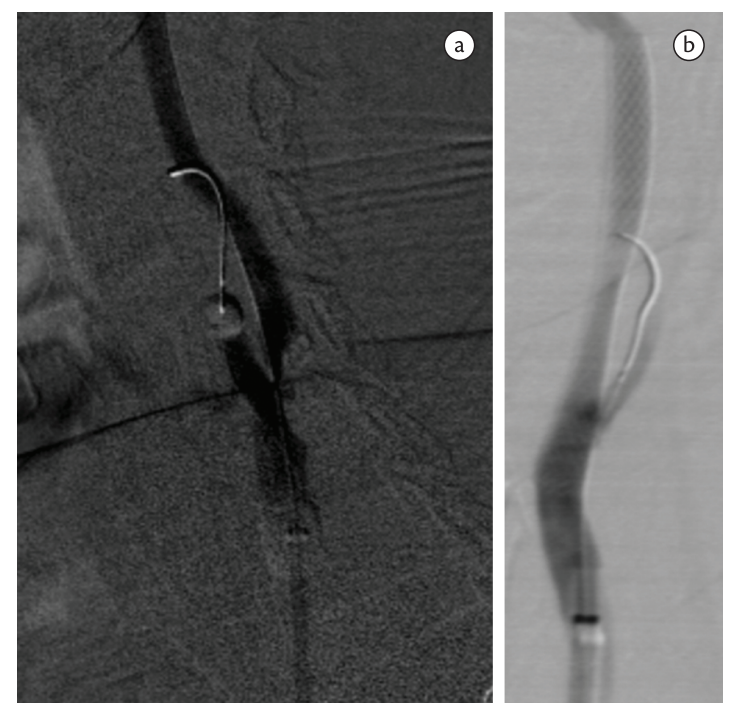

Figure 2. Digital angiographic images showing a) flow interruption in the common and external carotid arteries, and b) flow restoration after stent deployment and balloon deflation function were continuously monitored. In cases of intolerance to flow reversal, antegrade flow was restored via deflation of the balloon positioned at the common carotid artery.

Patients remained at the intensive care units of the participating centers for at least 24 hours after the procedure. Following neurological and hemodynamic assessment, patients were transferred to the ward and subsequently discharged.

\section{Outcomes of interest}

The following conditions were considered as major adverse events: transient ischemic attack, defined as the presence of neurological, motor, or cognitive deficit lasting for at least 24 hours; stroke, defined as the presence of neurological or cognitive deficit lasting for more than 3 days; and presence of acute myocardial infarction in patients presenting with two of the following criteria: precordial pain, electrocardiographic findings suggestive of ischemia and/or CPK-mb values showing at least a $4 \%$ increase in relation to normal levels, according to the criteria described by Clair et al. ${ }^{2}$ Minor adverse events assessed included hematomas at the puncture sites and pseudoaneurysms.

Procedures were considered to be technically successful when stent placement was performed with the use of the GORE Flow Reversal System ${ }^{\circledR}$ and when carotid angioplasty was completed (adequate stent placement and dilation of the occluded or stenotic area). Success rate, clinical outcomes and other variables were calculated as percentage incidence rates.

Flow reversal time was measured by one member of the surgical team, starting at inflation of the two balloons (external and common carotid arteries) and ending when both balloons were deflated. Mean flow reversal times recorded in the first 12 and the last 12 procedures were compared using Student's $t$ test.

All statistical analyses were performed using the Statistical Package for the Social Sciences (SPSS), version 17.0. Significance was set at $\mathrm{p}<0.05$.

\section{RESULTS}

The procedure was performed as planned (complete flow reversal) in all but three patients. In the patient presenting with carotid restenosis, only the balloon placed at common carotid artery was inflated. In another patient, the use of two protection systems was required, with occlusion of the common carotid artery and use of a distal protection filter, according to the seatbelt and airbag protection technique described by Schonholz et al. ${ }^{4}$ This decision was made based on 
the finding of circumferential atheromatous plaque distribution at the carotid bifurcation in this patient, rendering the use of the external carotid artery impossible. Finally, in another (third) patient, it was not possible to place the flow reversal system because an aortic arch type III was found.

Analysis of clinical comorbidities revealed that all 24 patients presented systemic hypertension, 14 (58.3\%) had diabetes mellitus, nine $(37.5 \%)$ had coronary disease, and two $(8.33 \%)$ were smokers. No other comorbidities were detected.

Aortic arch type II was the anatomic variation most commonly observed, present in 15 patients (62.5\%), compared with type III in six (25\%) and type I in three (12.5\%). The atherosclerotic lesion predominantly affected the common and internal arteries at the carotid bifurcation, namely in 19 patients (79.2\%), followed by lesion affecting the internal artery only in five $(20.8 \%)$. Table 1 shows the angiographic findings observed before and after the procedure.

The stents used in angioplasty were of the closedcell type in 16 patients $(66.7 \%)$. Table 2 shows the different stent models and lengths employed in the procedures.

All procedures were considered to be technically successful, except for the one case in which placement of the flow reversal system was not possible. Intolerance to flow reversal was observed in four cases $(n=23 ; 17.4 \%)$, and technical difficulties were experienced in one patient $(4.2 \%)$ while removing the occlusion balloon from the external carotid artery. Clinical outcomes included one case of stroke (4.2\%) and three $(12.5 \%)$ of hematomas at arterial puncture sites. Doppler ultrasound assessment of stent patency 30 days after the procedure showed patent stents in all patients.

Overall mean cerebral flow reversal time was 14.9 minutes (standard deviation of 4.7 minutes). A statistically significant decrease was observed in flow reversal time when comparing the first 12
(17.9 \pm 3.3 minutes) and the last 12 patients treated $(11.6 \pm 3.6$ minutes $)(\mathrm{t}=4.381, \mathrm{gl}=21, \mathrm{p}<0.001)$ (Figure 3).

\section{DISCUSSION}

The present study aimed to report our initial experience with the GORE Flow Reversal System ${ }^{\circledR}$ in carotid angioplasty. Although our sample is small, we strongly believe that our findings add to the existing literature by describing the early results obtained with the device in a different setting (Brazil).

Over the last decade, carotid angioplasty has become a consolidated treatment option for cerebral revascularization in symptomatic patients, in asymptomatic patients with contraindications to open surgery (endarterectomy), such as highrisk comorbidities, and also in patients with anatomic abnormalities that pose difficulties to open surgery ${ }^{5}$. Several randomized clinical trials have been conducted to show the safety and effectiveness of carotid angioplasty in comparison with endarterectomy, with variable results in terms of postoperative outcomes ${ }^{6-9}$. Most of them concluded that carotid angioplasty is not inferior to carotid endarterectomy.

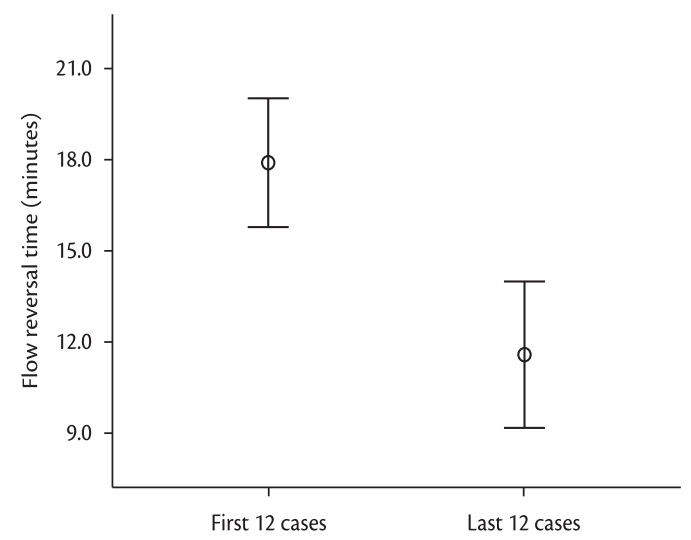

Figure 3. Mean cerebral flow reversal time in the first and second halves of the patients treated

Table 1. Angiographic findings on the contralateral side and in the cerebral region before and after carotid angioplasty.

\begin{tabular}{lcc}
\hline \multicolumn{1}{c}{ Angiographic finding } & $\mathrm{n}$ & $\%$ \\
\hline Collateral circulation, preoperative & & 23 \\
$\quad$ Contralateral internal carotid artery stenosis $<50 \%$ & 1 & 95.8 \\
Occluded contralateral internal carotid artery, or vertebral artery stenosis & 4.2 \\
Cerebral circulation, preoperative & 23 & 95.8 \\
$\quad$ Patent anterior and middle cerebral artery & 1 & 4.2 \\
Occluded anterior and middle cerebral artery & 23 & 95.8 \\
Cerebral circulation, postoperative & 1 & 4.2 \\
Patent anterior and middle cerebral artery & & \\
Occluded anterior and middle cerebral artery & &
\end{tabular}


Table 2. Types and lengths of the models employed.

\begin{tabular}{lcc}
\hline \multicolumn{1}{c}{ Stent type/length } & $\mathrm{n}$ & $\%$ \\
\hline Hybrid & & \\
Exact & 9 & 37.5 \\
Zilver & 3 & 12.5 \\
$\quad$ Cristalo & 1 & 4.2 \\
Open-cell & & \\
$\quad$ Precise & 4 & 16.7 \\
$\quad$ Protege & 4 & 16.7 \\
Closed-cell & & \\
Wall & 3 & 12.5 \\
Stent length & $3 \mathrm{~cm}$ & \\
$3 \mathrm{~cm}$ & & 29.2 \\
$4 \mathrm{~cm}$ & 7 & 70.8 \\
\hline
\end{tabular}

According to Ohki et al. ${ }^{10}$ the main limitation of carotid angioplasty is its potential for producing embolic debris. In fact, the same authors had already suggested the use of cerebral protection devices to reduce the risk of embolization during carotid stenting ${ }^{11}$. According to the authors, carotid angioplasty without cerebral protection is associated with a 3- to 4-fold higher risk of postoperative stroke or death. Coggia et al. ${ }^{12}$ showed that embolization may affect up to $15 \%$ of patients submitted to carotid stenting, with clinical manifestations being present in about half of them. Embolization has been associated with cognitive abnormalities,${ }^{13}$ dementia, and Alzheimer's disease ${ }^{14}$.

Macdonald, ${ }^{15}$ in a review about cerebral protection devices for use in carotid artery stenting, describes three different protection mechanisms: temporary (proximal or distal) occlusion of cerebral flow, use of filters, and flow reversal. The author points out that temporary balloon occlusion reduces the occurrence of microembolization, once it is able to capture particles as small as $60 \mu \mathrm{m}$ in diameter, compared with $140-\mu \mathrm{m}$ particles captured by filters. Nevertheless, cerebral flow reversal may be the first mechanism capable of effectively eliminating microembolization during carotid angioplasty. Gupta et al. ${ }^{16}$ used transcranial Doppler scan to monitor a group of patients submitted to endarterectomy and carotid stenting and showed that flow reversal systems were associated with lower rates of microembolization when compared with distal filters. Similar results were observed by Wholey et al. ${ }^{17}$.

The first reversal-of-flow cerebral protection device designed for use in carotid artery stenting was described by Parodi et al. ${ }^{18}$ The system allows the reversal of blood flow using balloons located inside the common and external carotid arteries, leading to proximal occlusion of the atherosclerotic lesion. The system was first called PAES (Parodi anti-embolism system), ${ }^{18}$ and was subsequently modified by Bates \& Campbell ${ }^{19}$. The system was approved by the Food and Drug Administration (FDA) in 2009, and is currently available under the trade name GORE Flow Reversal System ${ }^{\circledR}$ (WL Gore and Associates, Flagstaff, AZ, USA).

Different outcomes have been reported in association with the GORE Flow Reversal System ${ }^{\circledR}$. One possible explanation for such heterogeneous results is related to variations in the technical experience and expertise of the surgical team members involved in each study. In a review article including only multicenter studies designed to compare endarterectomy and angioplasty results, Macdonald ${ }^{20}$ emphasized the importance of surgical team experience for the success of both procedures. According to that author, the better outcomes reported in more recent studies, such as the Stenting versus Endarterectomy for Treatment of Carotid-Artery Stenosis $(\mathrm{CREST})^{9}$ and the International Carotid Stenting Study (ICSS), ${ }^{21}$ are probably related to the adoption of more rigorous criteria in the selection of patients and surgical team members.

In the present study, the principal investigator (first author) received training in a simulator provided by the manufacturer of the device and participated in two procedures performed at the University of Texas, in Dallas, USA, 2010. Moreover, prior to the beginning of the present study, the author had already performed more than 70 carotid angioplasties using different types of cerebral protection devices.

Mean age in our series was 71.2 years, very similar to the mean age reported in the EMPiRE study, ${ }^{2}$ of 70.2 years. With relation to comorbidities, our results were also similar to those observed by Clair et al. ${ }^{2}$ and Parodi et al. ${ }^{22}$ : there was a predominance of systemic hypertension, coronary disease, and diabetes mellitus.

Analysis of anatomic variations, especially the type of aortic arch encountered during the procedure, is important because it is useful in treatment planning and also because arch curvature is known to interfere with the degree of difficulty of the procedure ${ }^{23}$. In our series, aortic arch type II accounted for $62.5 \%$ of the cases, followed by arch type III, with $25 \%$. Although this finding could have posed some technical difficulties to the study, all cases were treated successfully, except for one patient with an aortic arch type III, in which it was not possible to place the 
flow reversal system. This finding corroborates the reliability of this cerebral protection system.

Preoperative angiographic findings provided indications for the use of flow reversal in the great majority of patients in our sample (contralateral artery stenosis $<50 \%$ in $95.8 \%$ ). The only exception was the patient in which the contralateral carotid artery was occluded. Kasirajan \& Brewster, ${ }^{24}$ in a 2-year study involving 53 patients, used flow reversal in six patients with contralateral occlusion and did not observe intolerance. In the EMPiRE trial $^{2}$ a rate of $11 \%$ of contralateral occlusion was observed in asymptomatic patients, compared to $9 \%$ in symptomatic ones. In spite of these positive findings reported for patients with contralateral occluded arteries and although contralateral stenosis $>50 \%$ was not included in our exclusion criteria, we decided to adopt a more conservative approach and did not indicate the procedure for our patient with an occluded contralateral carotid artery in this initial analysis.

According to Criado et al. ${ }^{25}$ in the presence of contralateral occlusion, collateral circulation is established via the circle of Willis, and cerebral blood flow is maintained. The results obtained by those authors confirmed this hypothesis, and several other studies have corroborated the importance of the circle of Willis for flow reversal and cerebral protection. ${ }^{2,22,24,26}$ In our sample, cerebral arteries were also monitored both before and after the procedure. In one case of our series, the cerebral anterior artery failed to fill, even after stent deployment, and the procedure was followed by a major adverse event in the immediate postoperative period (stroke).

In our series, closed-cell stents were used in $66.7 \%$ (16) of the patients, and the Exact ${ }^{\circledR}$ stent was the model most frequently employed, in $37.5 \%$ (nine) of the cases. Four-centimeter long stents were needed in $70.8 \%$ (17) of the patients. Closed cells and short lengths are desirable stent characteristics, ${ }^{2,22}$ because they prevent balloon entrapment and minimize difficulties while removing the balloon. Interestingly, in the case where technical difficulties were faced, an open-cell stent was being used, however there were no negative consequences for our patient in this case.

All cases of our series were technically successful, i.e., all patients were able to complete the angioplasty procedure, including the three cases where the use of the flow reversal system was not completed. In the one patient were placement of the flow reversal system was not possible, a FilterWire EZ ${ }^{\mathrm{TM}}$ Embolic Protection System Boston EZ protection filter (Boston Scientific, Natick, MA, USA) was employed.
This high success rate is in line with previous studies that have also reported successful outcomes with the same cerebral protection system. Adami et al., ${ }^{27}$ for example, reported a $97 \%$ success rate in a series involving 28 patients. In the EMPiRE study ${ }^{2}$ the use of flow reversal failed in only $3.7 \%$ of the cases, especially due to anatomic abnormalities, balloon rupture during inflation, or inability to adequately position the device. Parodi et al. ${ }^{22}$ also obtained a high rate of success $(99 \%)$, probably as a result of the careful selection of patients based on anatomic characteristics.

In our series, there were four cases $(n=23 ; 17.4 \%)$ of intolerance to flow reversal, a result that is higher when compared with previous studies. The EMPiRE ${ }^{2}$ study, for example, reported an intolerance rate as low as $2.4 \%$, with only $1.2 \%$ of the surgeries requiring interruption and no cases of permanent neurological impairment/deficit. Parodi et al. ${ }^{22}$ observed $3 \%$ of intolerance to flow reversal, with only one patient developing transient hemiparesis; in all other patients, balloons were reinflated and the procedure was completed. Although our intolerance rate was higher, only one of our patients lost consciousness, precisely the one with cerebral circulation abnormalities (Table 1). In addition, in all four cases, antegrade blood flow was restored and the balloons were successfully reinflated to allow the procedure to be completed. It is speculated that a phenomenon called preconditioning would take place after balloon deflation and would improve tolerance to flow reversal ${ }^{25}$.

We had one case $(4.2 \%)$ of major adverse event (stroke on the first postoperative day) in our sample, with no recovery after 30 days, in the patient with cerebral circulation abnormalities. Parodi et al. ${ }^{22}$ observed $1.5 \%$ of major adverse events in their sample (stroke and death) and $2 \%$ of transient ischemic attack (embolic cause in one patient and transient bradycardia-induced hemodynamic collapse in the remaining three). Nikas et al., ${ }^{28}$ in turn, did not record cases of stroke in the first 30 postoperative days, but found a $4 \%$ rate of stroke within 1 year. In the EMPiRE study, the rate of major adverse events (stroke, transient ischemic attack, acute myocardial infarction, or death) was $4.5 \%$.

With regard to minor adverse events, hematomas at arterial puncture sites were observed in three patients (12.5\%); all cases presented spontaneous resolution within 30 days, without pseudoaneurysm formation. Hospitalization time was not affected by these outcomes. The occurrence of hematomas in our sample is explained by some disadvantages of 
flow reversal systems, namely the need to use 9 or $10 \mathrm{Fr}$ introducer sheaths for arterial access and the need for an extra puncture at the femoral vein, using a 7 Fr introducer, which may pose difficulties when treating tortuous or small-caliper veins. The rate of perioperative hematomas observed in the EMPiRE study $^{2}$ was $3.7 \%$.

In addition to postoperative adverse events, we also decided to analyze flow reversal time, because of its indirect relationship with technical success. Overall mean flow reversal time was 14.9 minutes, and a statistically significant decrease was observed when comparing the first 12 and the last 12 patients operated by the surgical team. It is however important to emphasize that such difference did not have an impact on clinical outcomes, as also reported by Kasirajan \& Brewster ${ }^{24}$ and Clair et al. ${ }^{2}$ To the authors' knowledge, no other study so far has assessed flow reversal time, which hinders comparisons with the literature. Nevertheless, the significant results obtained after operating only 12 patients suggest a fast learning curve associated with this system.

In spite of our small sample size, our results are acceptable and compatible with the most important multicenter studies conducted worldwide ${ }^{2}$ and with other studies reporting preliminary findings with the same system, ${ }^{29}$ and they corroborate the effectiveness and safety of the GORE Flow Reversal System ${ }^{\circledR}$ for use in carotid angioplasty. In fact, from a different perspective, our sample size could be compared to the individual samples recruited by each center in the EMPiRE study (approximately 20 patients per participating center).

In sum, the low rate of adverse events observed in our study suggests the system's ability to prevent microembolization and consequently the occurrence of cognitive disorders in the postoperative period, whereas the significant decrease in flow reversal time suggests that the system is easy to learn and use. Future studies are warranted to compare this system with others currently available, and also to conduct different analyses, for example transcranial Doppler scan or cranial nuclear magnetic resonance, with the aim of improving our knowledge on the benefits of flow reversal systems in carotid angioplasty procedures.

\section{CONCLUSIONS}

These initial findings allow us to draw the following conclusions:
- The GORE Flow Reversal System ${ }^{\circledR}$ was safe and technically effective as a cerebral protection device during carotid angioplasty procedures.

- A significant and fast decrease in flow reversal time was observed with the use of the device.

- The rate of major (stroke) and minor (hematomas) adverse events were within acceptable limits.

\section{ACKNOWLEDGMENTS}

The authors are grateful to WL Gore and Associates for partially funding author training.

\section{REFERENCES}

1. Whitlow PL, Lylyk P, Londero $\mathrm{H}$, et al. Carotid artery stenting protected with an emboli containment system. Stroke. 2002;33:1308-14. PMid:11988608. http://dx.doi.org/10.1161/01. STR.0000013947.17575.B3

2. Clair DG, Hopkins LN, Mehta M, et al. Neuroprotection during carotid artery stenting using the GORE flow reversal system: 30-day outcomes in the EMPiRE Clinical Study. Catheter Cardiovasc Interv. 2011;77:420-9. PMid:20853365. http://dx.doi. org/10.1002/ccd.22789

3. Beneficial effect of carotid endarterectomy in symptomatic patients with high-grade carotid stenosis. N Engl J Med. 1991;325:445-53. PMid:1852179. http://dx.doi.org/10.1056/ NEJM199108153250701

4. Schonholz C], Uflacker R, Mendaro E, et al. Techniques for carotid artery stenting under cerebral protection. J Cardiovasc Surg (Torino). 2005;46:201-17.

5. Allaqaband S, Kirvaitis R, Jan F, Bajwa T. Endovascular treatment of peripheral vascular disease. Curr Probl Cardiol. 2009;34:359-476. PMid:19664498. http://dx.doi.org/10.1016/j.cpcardiol.2009.05.001

6. Yadav JS, Wholey MH, Kuntz RE, et al. Protected carotid-artery stenting versus endarterectomy in high-risk patients. N Engl J Med. 2004;351:1493-501. PMid:15470212. http://dx.doi.org/10.1056/ NEJMoa040127

7. Mas JL, Chatellier G, Beyssen B, et al. Endarterectomy versus stenting in patients with symptomatic severe carotid stenosis. N Engl J Med. 2006;355:1660-71. PMid:17050890. http://dx.doi. org/10.1056/NEJMoa061752

8. Ringleb PA, Allenberg J, Bruckmann H, et al. 30 day results from the SPACE trial of stent-protected angioplasty versus carotid endarterectomy in symptomatic patients: a randomised non-inferiority trial. Lancet. 2006;368:1239-47. http://dx.doi. org/10.1016/S0140-6736(06)69122-8

9. Brott TG, Hobson 2nd RW, Howard G, et al. Stenting versus endarterectomy for treatment of carotid-artery stenosis. N Engl J Med. 2010;363:11-23. PMid:20505173 PMCid:2932446. http:// dx.doi.org/10.1056/NEJMoa0912321

10. Ohki T, Roubin GS, Veith FJ, lyer SS, Brady E. Efficacy of a filter device in the prevention of embolic events during carotid angioplasty and stenting: An ex vivo analysis. J Vasc Surg. 1999;30:1034-44. http://dx.doi.org/10.1016/S0741-5214(99)70041-8

11. Ohki T, Marin ML, Lyon RT, et al. Ex vivo human carotid artery bifurcation stenting: correlation of lesion characteristics with embolic potential. J Vasc Surg. 1998;27:463-71. http://dx.doi. org/10.1016/S0741-5214(98)70321-0 
12. Coggia M, Goeau-Brissonniere O, Duval JL, Leschi JP, Letort $M$, Nagel MD. Embolic risk of the different stages of carotid bifurcation balloon angioplasty: an experimental study. J Vasc Surg. 2000;31:550-7. http://dx.doi.org/10.1016/S0741-5214(00)90317-3

13. Gaunt ME, Martin PJ, Smith JL, et al. Clinical relevance of intraoperative embolization detected by transcranial Doppler ultrasonography during carotid endarterectomy: a prospective study of 100 patients. Br J Surg. 1994;81:1435-9. PMid:7820463. http://dx.doi.org/10.1002/bjs.1800811009

14. Purandare N, Burns A, Daly KJ, et al. Cerebral emboli as a potential cause of Alzheimer's disease and vascular dementia: case-control study. BMJ. 2006;332:1119-24. PMid:16648133 PMCid:1459546. http://dx.doi.org/10.1136/bmj.38814.696493.AE

15. MacDonald S. Evidence for the routine use of carotid filters during carotid artery stenting. In: Becquemin JP, Alimy YS, editors. Controversies and updates in vascular surgery. Torino: Edizioni Minerva Medica; 2006. p. 128-31. PMid:16719422.

16. Gupta N, Corriere MA, Dodson TF, et al. The incidence of microemboli to the brain is less with endarterectomy than with percutaneous revascularization with distal filters or flow reversal. J Vasc Surg. 2011;53:316-22. PMid:21129899. http://dx.doi. org/10.1016/j.jvs.2010.08.063

17. Wholey $\mathrm{MH}$, Wholey $\mathrm{M}$, Bergeron $\mathrm{P}$, et al. Current global status of carotid artery stent placement. Cathet Cardiovasc Diagn. 1998;44:1-6. http://dx.doi.org/10.1002/ (SICI)1097-0304(199805)44:1<1::AID-CCD1>3.0.CO;2-B

18. Parodi JC, La Mura R, Ferreira LM, et al. Initial evaluation of carotid angioplasty and stenting with three different cerebral protection devices. J Vasc Surg. 2000;32:1127-36. PMid:11107084. http:// dx.doi.org/10.1067/mva.2000.109209

19. Bates MC, Campbell JE. Pitfalls of embolic protection. Tech Vasc Interv Radiol. 2011;14:101-7. PMid:21550513. http://dx.doi. org/10.1053/j.tvir.2011.01.008

20. Macdonald S. Contemporary randomized trials comparing CAS and CEA: a critique of the EVA-3S, SPACE, ICSS, SAPPHIRE, and CREST studies. Endovasc Today. 2010;10:50-96.

21. Ederle J, Dobson J, Featherstone RL, et al. Carotid artery stenting compared with endarterectomy in patients with symptomatic carotid stenosis (International Carotid Stenting Study): an interim analysis of a randomised controlled trial. Lancet. 2010;375:985-97. http://dx.doi.org/10.1016/S0140-6736(10)60239-5

22. Parodi JC, Schonholz C, Parodi FE, Sicard G, Ferreira LM. Initial 200 cases of carotid artery stenting using a reversal-of-flow cerebral protection device. J Cardiovasc Surg (Torino). 2007;48:117-24.
23. Cremonesi A, Zuffi A, Gieowarsingh S, Carvalho de Campos Martins E, Castriota F. Endovascular carotid interventions. Eurolntervention. 2010;5:866-70. PMid:20142205. http://dx.doi. org/10.4244/EIJV5I7A145

24. Kasirajan K, Brewster L. The Emory experience. Endovasc Today 2009;8:26-30.

25. Criado E, Doblas M, Fontcuberta J, et al. Carotid angioplasty with internal carotid artery flow reversal is well tolerated in the awake patient. J Vasc Surg. 2004;40:92-7. PMid:15218468. http://dx.doi org/10.1016/j.jvs.2004.03.034

26. Mehta M, Taggert JB, Sternbach $Y$, et al. The Albany Vascular Group experience. Endovasc Today. 2009;8:22-5.

27. Adami CA, Scuro A, Spinamano L, et al. Use of the Parodi anti-embolism system in carotid stenting: Italian trial results. J Endovasc Ther. 2002;9:147-54. http://dx.doi. org/10.1583/1545-1550(2002)009<0147:UOTPAE>2.0.CO;2

28. Nikas DN, Ghany MA, Stabile E, et al. Carotid artery stenting with proximal cerebral protection for patients with angiographic appearance of string sign. JACC Cardiovasc Interv. 2010;3:298-304 PMid:20298988. http://dx.doi.org/10.1016/j.jcin.2009.11.018

29. Hobson RW 2nd, Howard VJ, Roubin GS, et al. Carotid artery stenting is associated with increased complications in octogenarians: 30-day stroke and death rates in the CREST lead-in phase. J Vasc Surg. 2004;40:1106-11. PMid:15622363. http://dx.doi. org/10.1016/j.jvs.2004.10.022

Correspondence Sidnei José Galego

Av. Miro Vetorazzo, 115/68 - Bairro Demarchi CEP 09820-135 - São Bernardo do Campo (SP), Brazi Fone: +55 (11) 9957-2983

E-mail:sidjg@uol.com.br

Author information SJG, Faculdade de Medicina do ABC - FMABC, São Paulo, SP, Brazil. SJG, DFC), ACL , Instituto de Cirurgia Vascular e Endovascular de São Paulo - ICVE-SP, São Paulo, SP, Brazil. SJG, RD, MAPC, ANB, SG, Hospital São Luíz - Unidade Brasil, Santo André, SP, Brazil.

Author's contributions Conception and design: SJC Analysis and interpretation: SJG, RD, MAPC,SC Data collection: SJG, RD, MAPC, SG, ANB, DFC

Writing the article: SJC Critical revision of the article: $\mathrm{SJC}$ Final approval of the article*: SJG, RD, MAPC, SG, ANB, AL, DFC, JAC Statistical analysis: SJC Overall responsibility: SJC

*All authors have read and approved the final version submitted to I Vasc Bras. 